\title{
Supply control vs. demand control: why is resource tax more effective than carbon tax in reducing emissions?
}

\author{
Boqiang Lin (iD ${ }^{1} \&$ Zhijie Jia (iD) ${ }^{1 凶}$
}

Carbon tax and some other policies are designed to reduce emissions; resource tax can raise the energy price from the supply side to achieve the purpose of emission mitigation. Based on previous studies, this paper abstracts mitigation policies into supply-control (resource tax as an example) and demand-control (carbon tax as an example). The effects of these policies have been divided into the direct and the indirect effects. A dynamic recursive computable general equilibrium model is applied to simulate different impact path of the two policies. The research shows that if there is no foreign trade and the market is completely market-oriented, the effect of the demand control and the supply control may be equivalent. But this is not the real case. Under the same level of $\mathrm{CO}_{2}$ emission, carbon tax can significantly reduce the energy demand of enterprises and restrain energy imports. However, resource tax can significantly increase domestic energy prices firstly, and then enterprises will be more willing to use cheaper imported energy. Regardless of energy security, relatively low energy use costs ease the economic costs of emission mitigation. Therefore, if every country in the world is required to reduce emissions compulsorily, resource tax may be a better policy of reducing emissions while obtaining "excess profits". 


\section{Introduction}

Motivation. Energy and environmental problems are widespread. The abuse of fossil energy by humans has led to environmental degradation (Saboori and Sulaiman, 2013), resource shortages (Lozano et al., 2018), and global warming (Aune et al., 2016). Environmental issues and energy issues are currently the subject of more concern, and energy conservation and emission reduction are similar topics (Xu et al., 2014; Zhou et al., 2015, 2016). This is also a research concept advanced in this paper: carbon tax (CT) and energy resource tax $(\mathrm{RT})^{1}$ can reduce both of energy consumption and $\mathrm{CO}_{2}$ emissions. ${ }^{2}$

Many scholars are focusing on the reduction effect of those low carbon policies. The present authors are among those focusing on the mechanism, optimal prices, and goals of double control (emission reduction and carbon intensity reduction). The comparisons of these low carbon policies have never been interrupted and will be continued (Weitzman, 1974; Li and Jia, 2017), especially in the comparison between carbon Emission Trading Scheme (ETS) and carbon tax. Raux et al. (2015) studied the difference effects of these two policies on car travel behavior. Haites (2018) believed that ETS performed better than CT did in Europe, and similar results are found in Barragán-Beaud et al. (2018). Kosnik (2018) did an interesting research and found ETS wins hands down over CT in receiving more, and more positive, media attention in the US. Why are topics of policies such as CT (Hagmann et al., 2019; McLaughlin et al., 2019) and ETS (aus dem Moore et al., 2019; Wang et al., 2019) hotter than that of RT? Maybe CT and ETS were born to reduce emissions but RT were not. So, the former attracts a lot of attention of the public and scholars.

Carbon tax is a carbon dioxide emission tax imposed on energy users of energy after calculating carbon dioxide emissions from energy. It aims at protecting the environment and reduce global warming by reducing the emissions. Energy resource tax is a tax imposed on energy producers (energy production enterprises) to promote the rational use of energy resources. Both can affect on $\mathrm{CO}_{2}$ emissions mitigation positively. From the authors' perspective, carbon tax directly reduces the demand of energy-users, while resource tax directly reduces the energy production. So, the question can be transferred to the comparison between the supply control and the demand control. Will the effect be the same when it reaches the same marginal cost? How effective are the two emission reduction policies? What is the impact mechanism of the emission reductions of them?

What are the specific differences between the supply control and the demand control? Mainstream methods of emission reduction, such as $\mathrm{CT}$, help to reduce emissions by negative price incentives to energy consumption of the end-users (Ju and Fujikawa, 2019; Karapinar et al., 2019). Carbon tax aims at the cost of energy consumption, which means the subject is energy consumers who use energy. The first impact target of CT is energy demand. Resource tax on energy is quite different. The emission reduction mechanism of energy tax is to increase the price of energy use (theoretically, the energy price includes the cost of energy production, the profit of energy production enterprises and the tax revenue of the government, etc.). Energy taxes are aimed at the price of energy, which is the source of carbon dioxide emissions.

Strictly speaking, the impact of policy instruments on supply and demand is interactive, which means both resource tax and carbon tax could affect supply and demand. The different is that resource tax directly acts on the supply side, and then affects demand through price transmission mechanism. While carbon tax directly affects the demand side, then the reduction of supply will be achieved through the reduction of demand. It seems that if all energy users are fully covered in CT, CT and RT are equivalent, so the emission reduction effects of them are the same too. Is that the case?

Information asymmetry in RT and CT does exist. Energy production enterprises have the intrinsic incentive to hide their real output to avoid huge resource tax. Once a taxed energy commodity enters the market, it tends to be fully informative. Energy consumers also have the intrinsic incentive to hide the actual energy consumption to reduce carbon tax. It's hard to verify how much carbon dioxide companies emit and how much energy they consume, just like MRV (Monitoring, Reporting and Verification) in the ETS market. Large-scale MRV may lead to inefficiency in a market.

Thus, this paper holds the perspective that the supply control may be simpler and more effective than these mainstream emission mitigation methods with the demand control, such as CT. This paper, therefore, wants to answer the question whether and why energy tax is more effective than carbon tax in emission mitigation.

Literature review. Resource tax and carbon tax are two different kinds of taxes. Individuals or organizations that do mining business or produce and sell salt are taxpayers of resource tax (Zhong et al., 2018; Ge and Lei, 2018). The duty of resource tax is on the resource producers. Individuals or organizations that use energy causing carbon emissions are taxpayer of carbon tax (Pradhan et al., 2020). The duty of carbon tax is usually on energy users or emitters. According to the definition, it's clear that energy resource tax is part of resource tax. In this paper, the resource tax we are talking about is actually the energy resource tax that levy on primary fossil fuel producers. The relationship between resource tax and carbon tax is as follows:

1. In terms of tax scope, carbon tax and resource tax have certain overlap, both of which levy on fossil fuels.

2. In terms of effect, both carbon tax and resource tax have certain effects on carbon dioxide emission mitigation and energy conservation.

The differences between the two are:

1. In terms of appearance time, the appearance of resource taxes is earlier than that of carbon taxes. Carbon taxes are designed and emerged only after realizing that the emissions of greenhouse gases are destroying the ecological environment and causing global climate change.

2. In terms of the purpose, carbon tax is designed for reducing emissions, while the initial purpose of resource tax is not.

3. In terms of how to calculate the tax amount, the amount of carbon tax is calculated according to the carbon content or carbon emissions of fossil fuels, while resource tax is generally calculated by the amount of different kinds of energy.

4. In terms of tax base, the tax base of resource tax is the resource producers while that of carbon tax is energy users.

Resource tax is an important way to protect resources from abuse and to promote economic sustainability. China has continued to reform its resource tax, from salt sources to energy sources, from specific tax to ad valorem tax. And there are many researches focused on the process of reformation. Such as $\mathrm{Xu}$ et al. (2018) analyzed the impact of coal resource tax reform on $\mathrm{CO}_{2}$ reduction and haze by applying a computable general equilibrium (CGE) model, and found that increased coal resources tax inhibits resources consumption, improves resource utilization efficiency, and reduces haze emission and they suggest China should set coal resource tax carefully. Zhong et al. (2018) 
evaluated the effects of China's metal mineral resource tax reform by applying a CGE model. H. Li et al. (2018a, 2018b) focused on resource tax reform and economic structure transition in economies which is resource-based. Also, the impact of resource tax (or the reform of it) has been widely studied in China (Zhang et al., 2013; Liu et al., 2017; Tang et al., 2017), or in other resource-based countries (Orlov, 2015; Feng et al., 2018; Nong, 2018).

Since carbon taxes receive significantly more attention than resource taxes, carbon tax research is diverse than the latter. Some of the studies are on at the enterprises level. Such as, Insley (2017) developed a model for an energy production enterprise to choose the optimal timing of construction, production and abandonment in the context of carbon tax and finally identified Green Paradox. Chen and $\mathrm{Hu}$ (2018) modeled behavioral strategies of government and firms in the context of carbon tax and subsidy, and proved that carbon tax is more effective than subsidy to promote development of lowcarbon firms. He et al. (2018) studied on the trade-off between carbon tax and upgrade fee in enterprises under the tax and further discussed the impacts of carbon tax and enterprise's expected cost on its technology upgrade strategy.

Some of the literatures on carbon tax are at the macro level, such as, Leslie (2018) estimated short-run emission impacts under carbon tax under different market and showed the effects would be different in different production technologies and market structure. Berry (2019) focused on the distributional effects of France's introduced carbon tax recently and found that the tax may be useful to fight fuel poverty. Lin and Jia (2018) explored the impact of carbon tax rate and sectorial coverage on energy, environment and economy using CGE model. BarragánBeaud et al. (2018) compared carbon tax and emission trading in a perspective of economic and political feasibility in electricity generation sector. Yan and Eskeland (2018) found that carbon tax significantly shifts consumers toward lower-emission vehicles. Similarly, Lawley and Thivierge (2018) focused on the relationship between British Columbia's Carbon Tax and Household Gasoline Consumption and draw the similar conclusion. Mardones and Flores (2018) found that the emission reduction effect of carbon tax in Chile's industry will present an inverted-U shape. Bernard and Kichian (2019) confirmed that British Columbia's carbon tax has reduced the diesel demand since 2008.

Some literatures focused on energy tax and carbon tax. Zou et al. (2018) found domestic competitiveness improve when applying CT or RT, the result may be contrary to the prevailing perspective (Wang et al., 2011; Liang et al., 2016; Li et al., 2018b). As the study redefine the domestic competitiveness. The study established scenarios with different carbon tax rates and the combination of $\mathrm{CT}$ and RT, and finally concluded that compared with implementing a single tax, a combined carbon-energy tax reduces more emissions with relatively smaller economic costs. Chen et al. (2017) found that the energy saving and emission reduction effects of the carbon tax surpasses that of the energy tax under the equivalent tax revenue with even fewer significant negative impacts upon the economy. Similar results in electricity production enterprises can be found in Voorspools et al. (2005). Our results are different from Chen et al. (2017), as the "energy tax" that paper defined are not the energy resource tax in this paper. The "energy tax" that paper used to simulate is the tax on final energy consumption, which means energy users are on the duty of "energy tax", not the producer. Moreover, there is less detailed analysis of its impact mechanism. This paper will take a step further in this kind of comparison, and the aim and scope of this paper are different. We focus on the comparison between RT and $\mathrm{CT}$, and the different mechanism and effect of the two emission reduction policies.

Purpose and structure. This paper will focus on the comparison between RT and CT, and try to answer why RT is more effective, and why those specific effects could happen. The basic structure of this paper is: the motivation, literature review and purpose are presented in "Introduction" section. The scenario design is described in section "Scenarios setting". Methodology are introduced in section "Methodology and data source". The simulation results and discussions are provided in section "Results and Discussion". The conclusions and policy implications are proposed in section "Conclusions, Policy implication, and Limitations".

\section{Scenarios setting}

Nordic Europe is a region where carbon tax was implemented earlier. They have relatively mature experience to draw lessons from. In 1992, Denmark became the first country to impose a carbon tax on households and businesses. Part of the carbon tax revenue is used to subsidize energy-saving projects for industrial enterprises, while companies enjoy tax returns and discounts. Therefore, the actual carbon tax rate in the industrial sector is equivalent to about $35 \%$ of the household tax rate. ${ }^{3}$ Thus, this paper assumes the CTD scenario as patterns of Denmark's carbon tax policy. And we assume a CTQ scenario as the scenario that the government does not impose a carbon tax on residents, which is based on Quebec's carbon taxation in Canada. Moreover, this paper assumes additional resource tax is levied in RTC and RTA scenarios. Only coal resource tax is levied in the former scenario, and all kinds of primary fossil fuel are covered in the taxation in the latter scenario. We assume CT or RT will be implemented in 2020 .

Moreover, this study compared scenarios with and without the price controls. With the presence of the price controls, we assumed that the government regulates the domestic producing price of crude oil and natural gas. Instead of controlling the consumption price directly, the government controls the production price through taxation or subsidy indirectly. Therefore, an endogenous virtual tax is introduced to represent the properties of the price controls. Due to the prices of the oil and gas market are controlled in China while the coal market has basically completed the market-oriented reform. This paper assumes that the prices of oil and gas market are controlled in CTD, CTQ, RTC, and RTA scenarios by introducing a virtual tax in the two markets. While FCTD, FCTQ, FRTC, and FTTA scenarios simulate the condition that all the markets are without the price control compared with CTD, CTQ, RTC, and RTA scenarios, respectively. The scenarios setting is shown in Table 1.

According to the introduction of the eight scenarios in this paper above, here we summarize the logic of these scenarios. The first two scenarios, the CTD and CTQ scenarios, are used to

\section{Table 1 Simulation scenarios.}

\section{Scenarios Description}

BAU

CTD

\section{CTQ}

RTC

RTA

FCTD

FCTQ

FRTC

FRTA
Bussiness as usual

Carbon tax based on Denmark's experience (carbon tax on both household and enterprises and the tax rate ratios: 1:0.35)

Catbon tax based on Quebec's experience (only enterprises are covered in carbon tax)

Resource tax with coal market

Resource tax with all kinds of primary fossil fuel market

Free market condition of CTD

Free market condition of CTQ

Free market condition of RTC

Free market condition of RTA 


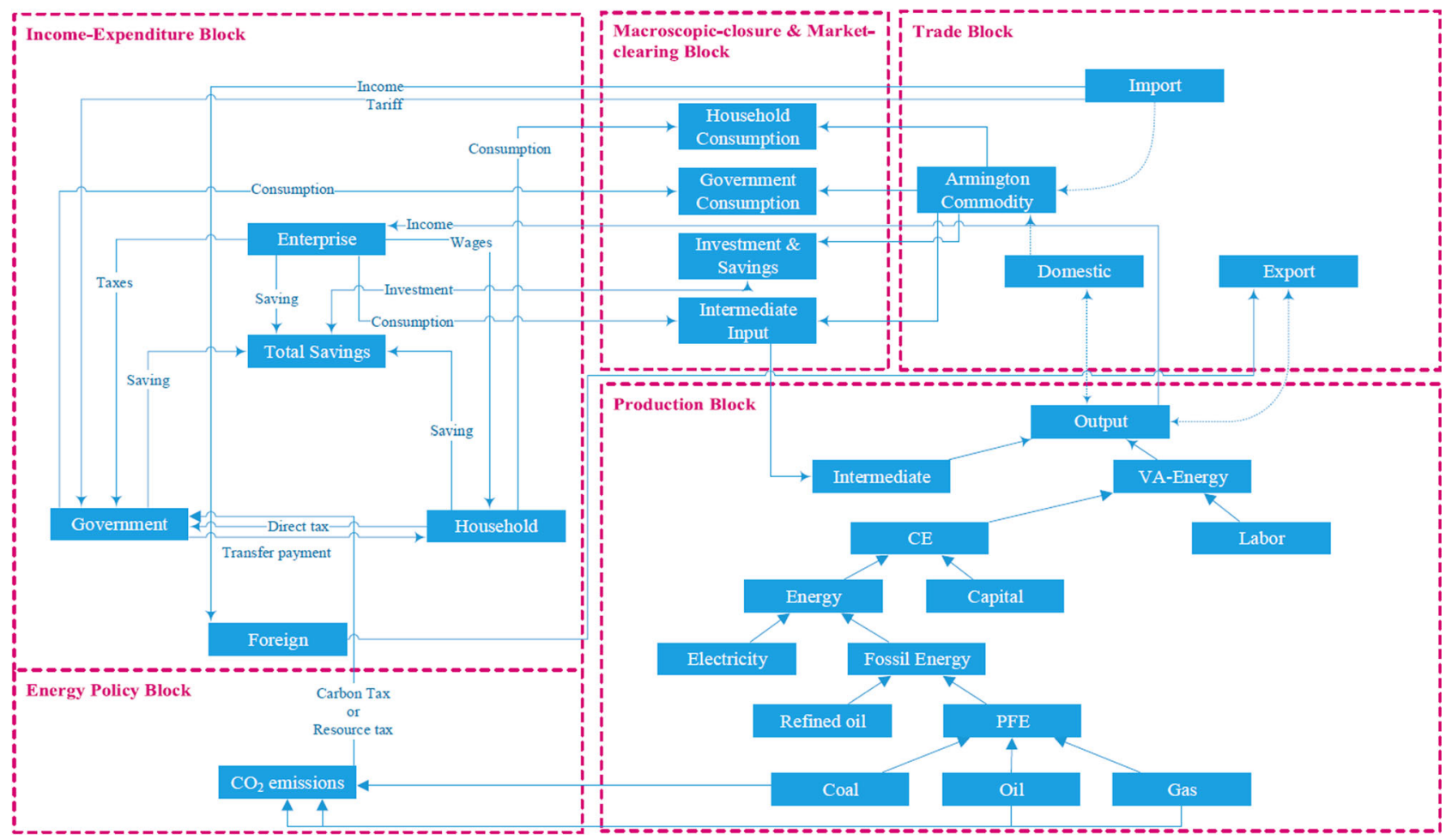

Fig. 1 Framework of CEEEA/CGE model in this paper. The model consists of five blocks: production block, income-expenditure block, trade block, energy policy block, and macroscopic-closure and market-clearing block.

simulate what would happen under different carbon tax experience (Denmark and Quebec). The RTC and RTA scenarios are used to simulate the conditions that resource taxes on coal or all kinds of primary fossil fuel increase to a certain degree. As the price of refined oil market is controlled by government in China, we need to consider this factor into our model and to see if the market regulation influences the effectiveness of carbon tax and resource tax. So, the FCTD, FCTQ, FRTC, and FRTA scenarios are created to simulate the condition that the refined oil market is a free market instead of regulated one.

\section{Methodology, data source and assumptions}

CEEEA/CGE model. In order to complete such a simulation analysis without real practice, CGE model is utilized in this paper, which could easily explore the impact environment, energy and economy impact, as Computable General Equilibrium (CGE) model is widely used for analysis of policy impact (Arndt et al., 2012; Allan et al., 2014). Different from input-output analyses (Apesteguia and Ballester, 2015) or game theory analyses (Kajackaite and Gneezy, 2017), CGE models are able to analyze the impact of target issue on the whole society better. We summarized 3 characteristics of CGE model (Bjerkholt et al., 2016; Massiani, 2018).

1. The supply and demand functions clearly reflect the behavior of producers pursuing profit maximization and consumers pursuing maximization of utility.

2. The quantity and relative price are both endogenous in the model, and the resource allocation method is determined by the general equilibrium model structure with Walras's law.

3. The focus of this model is on simulating the physical aspect of the economic entity. The resources of the economy in the model have been fully utilized.

CGE model in this paper consists of five blocks: production block, income-expenditure block, trade block, energy policy block and macroscopic-closure and market-clearing block, named CEEEA model (China Energy-Economy-Environment Analysis), which model is improved based on Lin and Jia (2019). The framework is shown in Fig. 1. And equation system is shown in Appendix.

Data source. China Input-Output Table is used to construct Social Accounting Matrix (SAM) which is a basic data of CGE model (China Input-Output Association, 2015). For analyze energy issues, an energy balanced table is constructed in this paper and the data of this table is from China Statistical Yearbook (National Bureau of Statistics, 2015). Compared with Global Carbon Budget 2017 (Le Quéré et al., 2017), we declare that the $\mathrm{CO}_{2}$ emission we discusses is only from energy consumption, without Biological breath, microbial decomposition, and carbon sinks and carbon emissions from land and sea. We reclassify the 139 sectors in the CIOT into 14 departments, as shown in Table 2. Other detailed information is illustrated in Appendix B.

Assumptions. As many papers does not make a comparison of emission reduction policies based on the same benchmark (Chen et al., 2017; Li and Jia, 2017; Haites, 2018; Barragán-Beaud et al., 2018), or compare emission reduction policies from other perspective (Kosnik, 2018). Thus, this paper tries to fill the knowledge gap.

In order to ensure the same benchmark when comparing these scenarios, $\mathrm{CO}_{2}$ emissions are exogenous variable and under control in CEEEA/CGE model, which means $\mathrm{CO}_{2}$ emissions in all the Counter Factual (CF) scenarios are the same. We assume that ETS in all CF scenario will start in 2017 and the peak year is 2022 by 10.94 billion tons of $\mathrm{CO}_{2}$, as shown in Fig. 2, which emissions are set in line with the goal of "double control" in China (the target of carbon emissions and carbon intensity before 2030). Then the emissions will drop to 9.97 billion ton in 2030 in CF scenario. While in BAU scenario, the emissions will increase from 
Table 2 Description of industry classification and population classification.

\begin{tabular}{ll} 
Abbr. & Industries \\
\hline AGR & Agriculture, forestry, animal husbandry, and fishery \\
COL & Coal mining and washing industry \\
OIL & Petroleum exploitation \\
GAS & Natural gas exploitation \\
REF & Refined oil \\
CMC & Chemicals \\
MTL & Metal smelting and rolling products \\
MTP & Metal products \\
ELC & Electricity \\
TRA & Transportation, warehousing, and postal services \\
CST & Construction \\
RST & Real estate \\
OTH & Other industry \\
SER & Services \\
RUR & Rural residents \\
CTZ & Urban residents \\
\hline
\end{tabular}

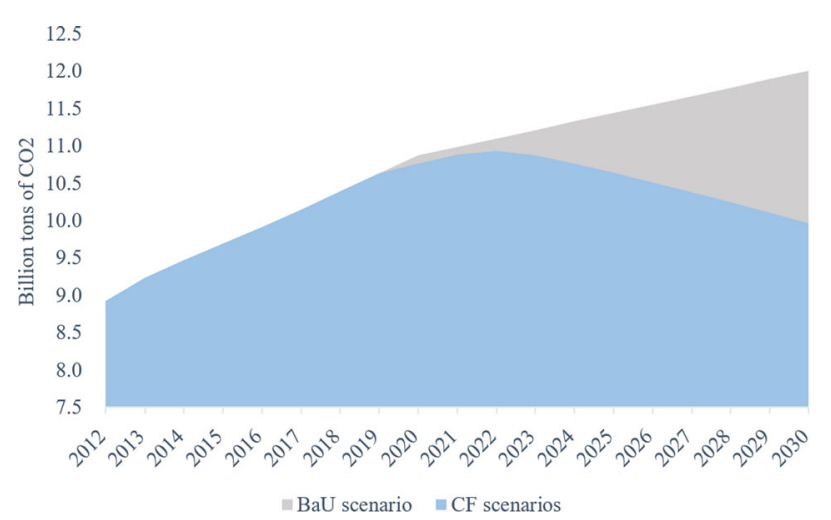

Fig. $2 \mathbf{C O}_{\mathbf{2}}$ emissions in $\mathrm{BaU}$ scenario and $\mathbf{C F}$ scenarios. We assume that the $\mathrm{CO}_{2}$ emissions will peak in 2022 in all counter factual scenarios imposing resource tax or carbon tax, while there is no peak in $\mathrm{CO}_{2}$ emissions in BaU scenario.

8.92 billion tons of $\mathrm{CO}_{2}$ in 2012 to 12.01 billion tons of $\mathrm{CO}_{2}$ in 2030 (in this scenario, the emission is endogenous variable). Then we make carbon tax rate and energy tax rate endogenous for seeking the optimal tax rate to achieve emission reduction targets.

In the conditions of the price controls, this paper introduce a conception of virtual tax (Hoffmann, 2003; Konan and Van Assche, 2007). In this condition, tax rate is an endogenous variable but the crude oil and natural gas prices are an exogenous variable. Readers should be noted that the prices here are prices of domestic output for domestic consumption in Fig. 1, which is $P D_{i}$ in Eq. (A.35) in Appendix. The reason of controlling the price of domestic output for domestic consumption, instead of consumer price is that government can only control (subsidize or tax) domestic enterprises, however, government cannot intervene in international markets and consumers.

\section{Results and discussion}

Basic results

$\mathrm{CO}_{2}$ emissions. As $\mathrm{CO}_{2}$ emissions in this paper is an exogenous variable, it is an assumed variable. We assume that carbon tax or resource tax in all CF scenario will start in 2020 and the peak year of $\mathrm{CO}_{2}$ emissions is 2022, as illustrated in Fig. 2. All the emissions in CF scenarios are the same (during 2020-2030, $\mathrm{CO}_{2}$ emission is an exogenous variable in $\mathrm{CF}$ scenario and carbon tax rate or resource tax rate becomes endogenous, so that we can study economic losses at the same level of emission reduction. Such modeling setting indicates that $\mathrm{CO}_{2}$ emissions in all $\mathrm{CF}$ scenarios can meet the goals of China's Intended Nationally Determined Contributions.

GDP. Gross Domestic Output (GDP) is usually used to measure the economic performance. GDP performance in 2030 in all scenarios and reduction rate of GDP are depicted in Fig. 3. 2030 GDP will be 100.39, 98.45, 98.44, 98.34, 98.34, 98.57, 98.55, 99.68, and 99.55 billion CNY in BaU, CTD, CTQ, RTC, RTA, FCTD, FCTQ, FRTC, and FRTA scenarios, respectively. The reduction rate will be $1.97,1.98,1.05,1.05,1.85,1.86,0.71$, and $0.85 \%$ in CTD, CTQ, RTC, RTA, FCTD, FCTQ, FRTC, and FRTA scenarios, respectively.

For a more intuitive understanding of the figures in this paper. We use different colors to refer to different scenarios, as showing in the following charts. Blue represents carbon tax, and green represents resource tax. Deeper color means the scenarios without the price control. We can summary the findings in Fig. 3.

1. The result of model simulation is obviously inclined to resource tax. The emission reduction efficiency of resource tax is obviously greater than that of carbon tax. GDP losses in carbon tax scenarios are much higher than those in resource tax scenarios. The loss is nearly double in pricecontrolled condition and is more than twice in free market condition.

2. The price control would be harmful to economic performance when implement carbon tax or resource tax. Free market will mitigate the loss by 0.12 to $0.34 \%$, especially in resource tax scenarios. That is, if the crude oil and natural gas market is out of the price control, economic gains in resource tax will be $0.21-0.34 \%$.

3. Resource tax of oil and gas will make no sense if the price is controlled in the market. If the government control the price, the price won't change even we add an additional resource tax. The price variations will not be transmitted to downstream enterprises. So, the results in RTC and RTA scenarios are totally the same, while those in FRTC and FRTA scenarios are different.

Social welfare. Many studies have explored whether carbon taxes are regressive or progressive. They measured the issue in different perspectives, such as income and social welfare among different people (Speck, 1999). We also consider the whether RT or CT is regressive by ultility level (social welfare) measured by currency. A method like Laspeyres Price Index is used to eliminate the impact of price levels in different periods. Then we can define an indicator of social welfare based on Hicksian equivalent variation (Hosoe et al., 2010). In this paper, The utility function is Cobb Douglas function. We can calculate utility in different period by Eqs. (1) and (2). And then we can calculate the social welfare change by Eq. (3).

$$
\begin{gathered}
U U 0=\prod_{i} X P 0_{i, 0}^{\alpha_{i}} \\
U U_{t}=\prod_{i} X P 1_{i, t}^{\alpha_{i}} \\
E V=\frac{U U_{t}}{\prod_{i}\left(\alpha_{i} / P Q 0_{i}\right)^{\alpha_{i}}}-\frac{U U 0}{\prod_{i}\left(\alpha_{i} / P Q 0_{i}\right)^{\alpha_{i}}}
\end{gathered}
$$

Figure 4 illustrates social welfare change in 2030 based on BAU scenario. We found that tax on both household and enterprises may be regressive in Denmark experience, which is the same as the conclusions of previous study (Wier et al., 2005). But others, seem to be progressive. Just as Pizer and Sexton (2019) pointed, 


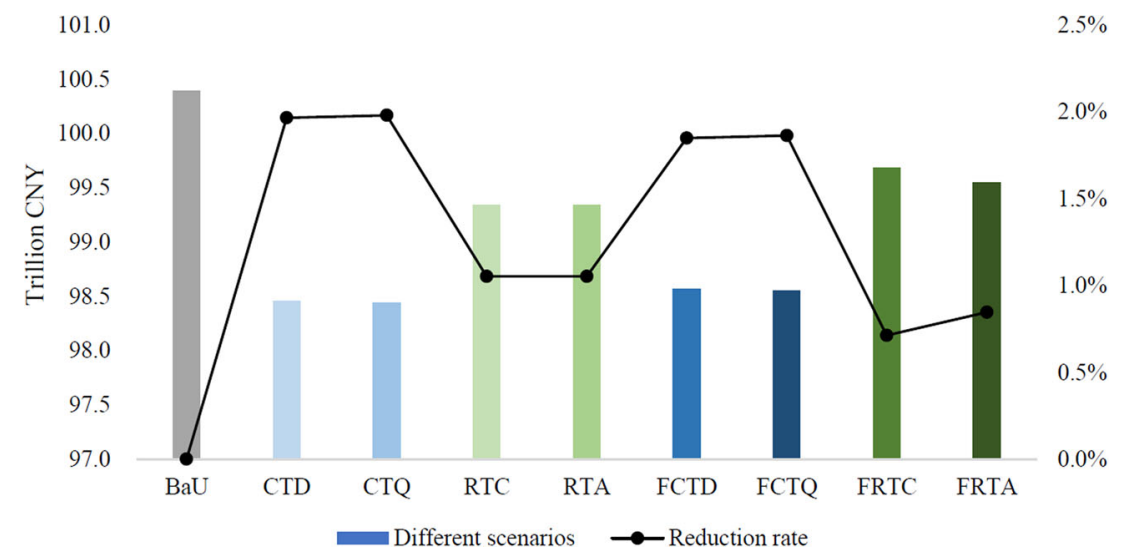

Fig. 3 GDP in 2030 and GDP loss rate compared with BAU scenario. Blue bars are scenarios imposing carbon taxes, and green bars are scenarios imposing resource taxes. Deeper colors represent free market condition in these scenarios. Please refer to Table 2 for industry abbreviations.

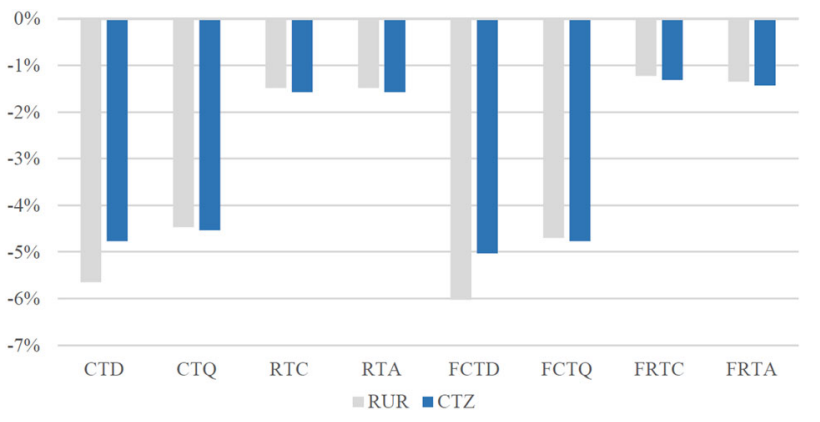

Fig. 4 Social welfare change in $\mathbf{2 0 3 0}$ based on BAU scenario. RUR for rural residents, CTZ for urban residents.

energy taxes need not be as regressive as is often assumed, because there are many factors influencing effect of energy taxes. Perhaps because the commodities consumed by urban people have a higher carbon footprint, if carbon tax is levied on enterprises, or directly raising energy prices by levying resource tax, the emission reduction cost (or the cost of energy use) will tend to accumulate along the carbon footprint gradually to the final consumption. Like bioconcentration, the closer the organism is to the top of the food chain (the position of industrial chain), the higher the accumulation of endotoxins (environmental tax costs). Evidence can be found in China Input Output Table. Through the total input coefficient of input-output table in China, we find that the traditional energy intensive industries with high total fossil fuel input coefficient, such as petroleum, petrochemical, chemicals, metal products, electric power. However, transportation and services also hold high total fossil fuel input coefficient, such as public transportation, wholesale, retail, finance, leasing, and scientific and technological research. However, most of them are consumed by urban residents rather than by rural residents, no matter in quantity or proportion. Thus, due to the different consumption preference, resource tax seems to be a kind of more progressive one. Another, relative to carbon tax, resource tax can mitigate the negative impact of social welfare caused by emission reduction. and free market help to reduce the negative impact in $\mathrm{RT}$ scenarios. However, the free market cannot help it in carbon tax.

\section{Discussions}

Domestic market. Figure 5 illustrates the industrial output changes in 2030. Compared with $\mathrm{BaU}$ scenario, the output of coal production will decrease by $18.81,18.83,32.03,32.03,20.55$, $20.57,38.00$, and $34.90 \%$ in 2030 CTD, CTQ, RTC, RTA, FCTD,
FCTQ, FRTC, and FRTA scenarios, respectively. Crude oil output will reduce by $56.86,56.83,53.60,53.60,26.89,26.95,3.27$, and $30.01 \%$ in 2030 CTD, CTQ, RTC, RTA, FCTD, FCTQ, FRTC, and FRTA scenarios, respectively. The output changes of natural gas are similar to the changes of oil. Electricity output will reduce by $31.62,31.69,4.26,4.26,35.08,35.15,5.28$, and $4.76 \%$ in 2030 CTD, CTQ, RTC, RTA, FCTD, FCTQ, FRTC, and FRTA scenarios, respectively.

Based on the comparison, some evidences show why resource tax have better performance in emission reduction. Firstly, coal production in RT scenarios will reduce greater than that in CT scenarios will. Electricity production will not be greatly affected in RT scenarios, as well as petroleum refining industry. As for other non-energy production industries, the reduction in output will be mitigated in RT scenarios compared with CT scenarios.

Abandoning the price control in oil and gas market could increase the efficiency of emission reduction. The output of coal will reduce more in the free market than that in price-controlled scenarios, especially in the context of resource tax. In free market, oil and gas output will be much more than that in pricecontrolled scenarios. It seems that the society is more refer to consume oil and gas when Chinese government opens the crude oil and natural gas market. But, why would this happen? The authors refer to the China's Input-Output Table for seeking the answer. We found that sum of the complete consumption coefficients of the oil and gas industry is far more than that of coal industry (coal:oil and gas $=2.74$ : 3.27 ). Then we sum up the coefficients by weighting added value or total output, the number in coal consumption is also lower than that in oil and gas consumption (if weight is value-added, then coal :oil and gas $=2892: 3097$; if weight is domestic output, then coal : oil and gas $=10836: 11900)$. It indicates that oil and natural gas have a higher economic driving role.

Figure 6 illustrates consumer price of commodities. Commodity price will increase in all industries in all CF scenarios. Primary energy price (such as coal, oil, and gas) will increase the most in RT scenarios while the price of secondary energy will rise the most in CT scenarios. This is the biggest difference between the two kinds of scenarios. It seems like the burden will be shared by different energy consuming industries in CT scenarios compared with RT scenarios, especially in energy conversion industries.

Resource tax could rise the cost of energy production, and the increasing price will transmit the cost to the downstream enterprises. Carbon tax will increase the cost of energy consumption. Intuitively, carbon tax with full industry coverage may have the same effect with resource tax with full primary energy coverage, but the effects are totally different, as depicted in 


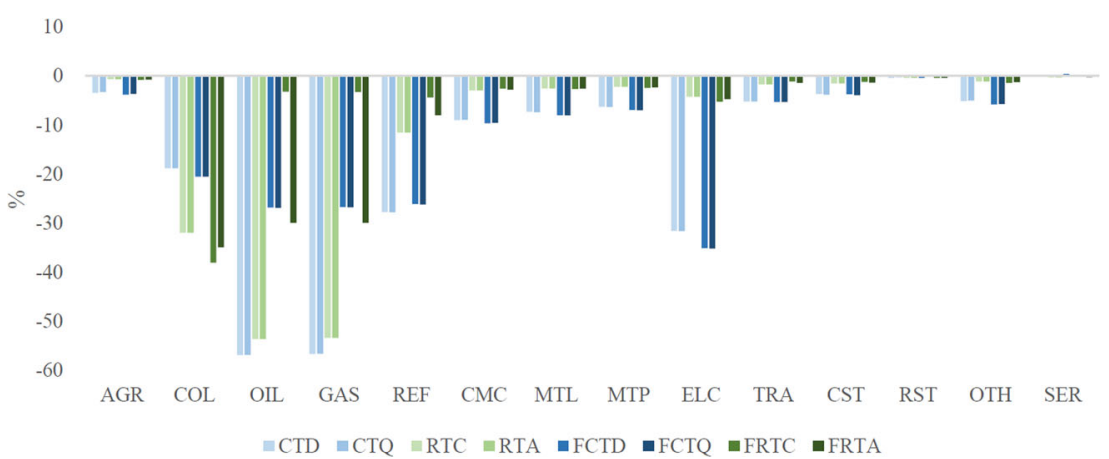

Fig. 5 Industrial Output changes in 2030. Blue bars are scenarios imposing carbon taxes, and green bars are scenarios imposing resource taxes. Deeper colors represent free market condition in these scenarios. Please refer to Table 2 for industry abbreviations.

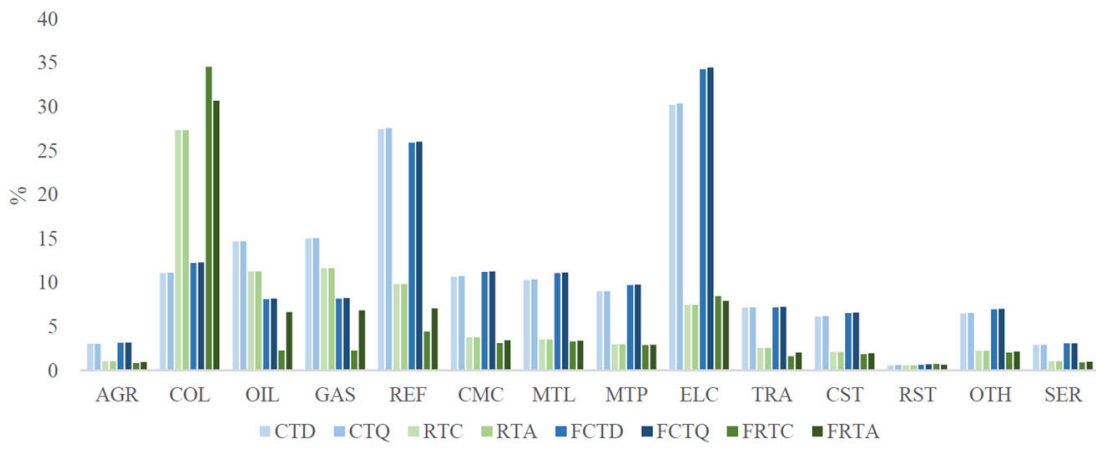

Fig. 6 Commodity price changes in 2030. Blue bars are scenarios imposing carbon taxes, and green bars are scenarios imposing resource taxes. Deeper colors represent free market condition in these scenarios. Please refer to Table 2 for industry abbreviations.

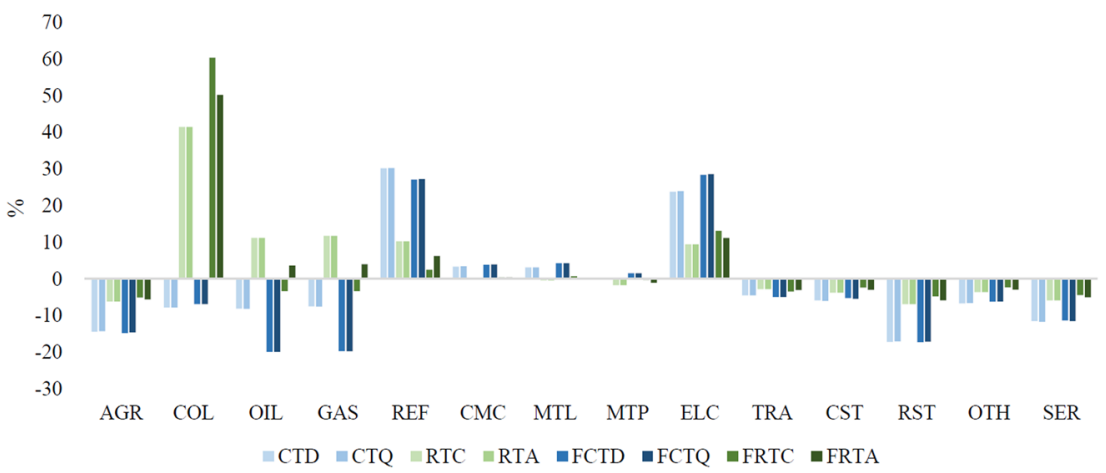

Fig. 7 Import changes in 2030. Blue bars are scenarios imposing carbon taxes, and green bars are scenarios imposing resource taxes. Deeper colors represent free market condition in these scenarios. Please refer to Table 2 for industry abbreviations.

Fig. 6. Why does this happen? Because that kind of idea ignores the fact that international market will mediate and reallocate the factor market. In RT scenarios, if domestic energy prices are too high, energy users can buy more energy from international market, but in CT scenarios, they cannot. You have to pay taxes as long as you use it, wherever you buy. This phenomenon can refer to section "International market".

International market. Import and export changes of energy commodity in 2030 is illustrated in Figs. 7 and 8. Both RT and CT can significantly reduce energy export. However, there is no significant reduction in oil and gas export in FRTC scenario. Because in this scenario, only government only tax on coal production, instead of all primary fossil energy. Coal export will suffer a bigger loss in RT scenarios than that in CT scenarios, because the domestic coal price in RT scenarios is higher than that in CT scenarios so that domestic energy production enterprises have lost their international competitiveness in the context of RT. The import of fossil energy will increase in RT scenarios, because of the higher energy prices, so that energy consumers will be more willing to use imported energy in the context of RT. However, the import will decrease in CT scenarios, as government will also tax on the enterprises who use imported energy while government in RT scenarios will not. To sum up, considering international trade, RT scenarios' better economic performance partly depends on more low-cost energy imports, absorbing dividends from energy export countries.

The results show that carbon tax will not promote energy imports. But according to section "Domestic market", domestic energy prices increase so that energy imports should increase because of substitution effects. But why will the energy import in carbon tax scenarios go down? CT first reduces the demand of energy users for energy, then, they will reduce energy consumption (both domestic one and imported one). Take crude oil as an 


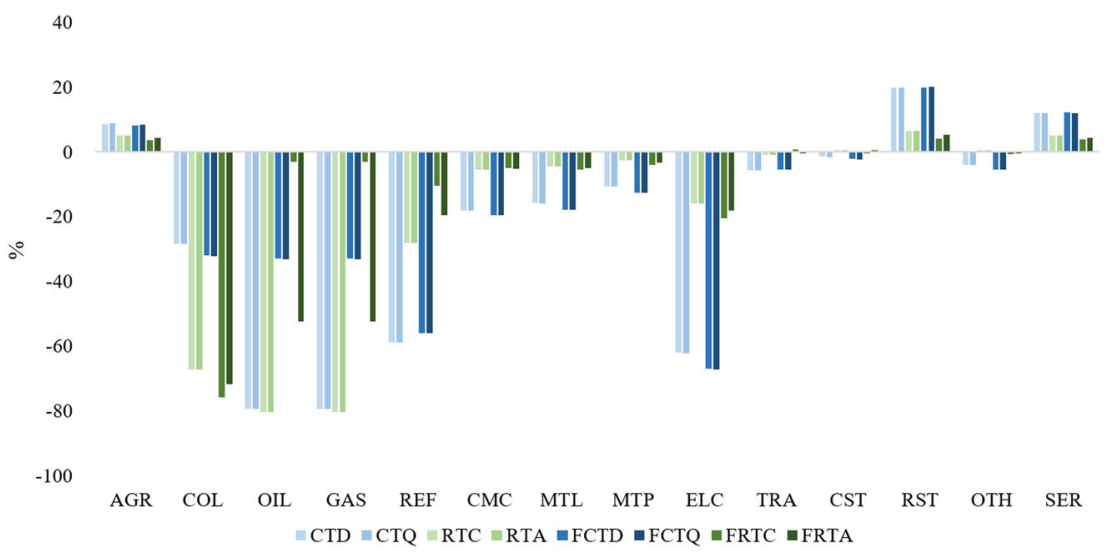

Fig. 8 Export changes in 2030. Blue bars are scenarios imposing carbon taxes, and green bars are scenarios imposing resource taxes. Deeper colors represent free market condition in these scenarios. Please refer to Table 2 for industry abbreviations.

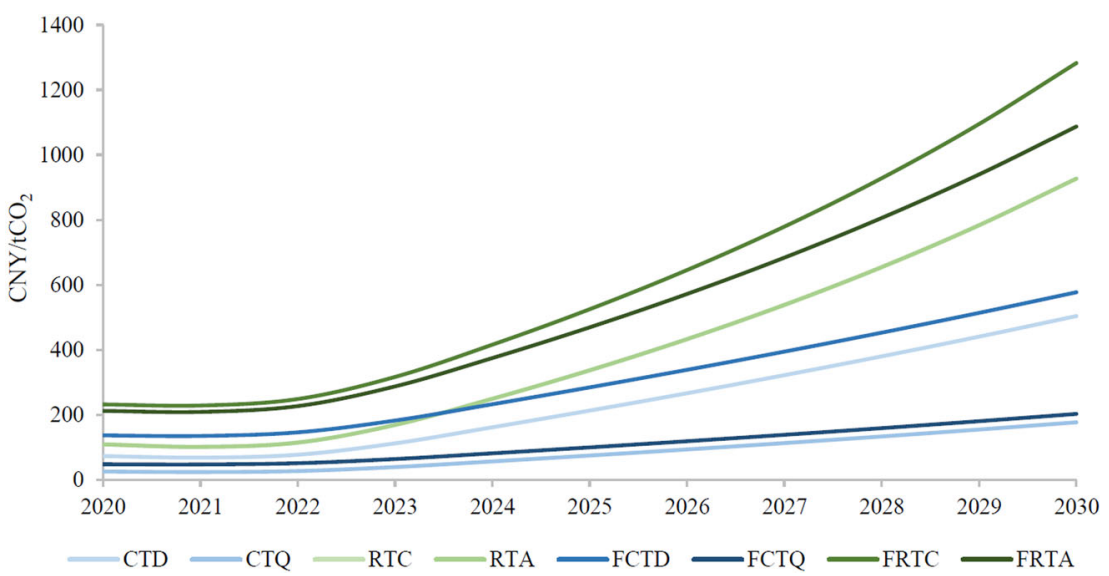

Fig. 9 Carbon tax and resource tax from 2020 to 2030. Blue lines are scenarios imposing carbon taxes, and green lines are scenarios imposing resource taxes. Deeper colors represent free market condition in these scenarios.

example, the rising oil prices in carbon tax scenarios will increase the proportion of oil import (that is, oil dependency) because of substitution effects, but cannot increase the total amount of oil import as the total demand is reduced. But in resource tax scenarios, the energy prices rise much higher than those in carbon tax scenarios, so with the high substitution effect, both oil dependency and oil import will increase.

Another, as Fig. 5 shows, coal output is reduced greater in RT scenarios than that in CT scenarios, but the output of electricity is in reverse. When we consider the changes of international market, the reasons are clear. Coal import is soaring when resource tax is implemented (Fig. 7) which lead to the total coal consumption of electricity industries in RT scenarios is even a little higher than that in CT scenarios. It is coal imports that support the high output of electricity in RT scenarios.

Tax rate and government tax. Figure 9 shows us the rate of carbon tax and resource tax from 2020 to 2030 . To facilitate comparison, we converted the unit of resource tax rate into $\mathrm{CNY} /$ tons-of- $\mathrm{CO}_{2}$ by calculating carbon content. To meet the same reduction goal, resource tax rate should be higher than carbon tax rate. The main reason is that the tax base is different. Resource tax will be only collected from energy production enterprises, but the carbon tax will be collected from all enterprises, even household. Faced with higher carbon emission constraints, tax rates are also increasing over time. In addition, we found that if we want to reduce tax burden for enterprises, carbon tax rate must be doubled to achieve the same reduction goal (comparing CTD scenario with CTQ scenario, or comparing FCTD scenario with FCTQ scenario).

Government revenue changes is shown in Table 3. Similar to other literatures (Marron and Toder, 2014; Lontzek et al. 2015; Jia and Ma, 2017), government will increase the income due to higher tax rate. Most revenue are from enterprises, or indirect tax. Government will get more revenue in carbon tax scenarios, increasing total revenue by $14.80-17.69 \%$, while the increase will be $3.44-3.70 \%$ in RT scenarios. The reason is that there is a wider taxation community in carbon tax. Although the government will invest and consume with this huge income, the efficiency of government spending is lower than that of enterprises. Maybe this is another reason why RT's economic performance is better than CT's. Another point should be noted that free market could let government gain more than price-controlled market does.

Coal and electricity consumption. The consumption of coal in different scenarios in 2030 are depicted in Fig. 10. The bar and the coordinates on the left represent coal consumption. The line and the coordinates on the right represent change rates in coal consumption in 2030. Coal consumption will be 3321.33 Million tons of coal equivalent (Mtce) in $2030 \mathrm{BaU}$ scenario. The consumption will be $2686.67,2686.90,2542.22,2542.22,2634.31$, 2634.73, 2419.19, and 2483.16 Mtce in CTD, CTQ, RTC, RTA, FCTD, FCTQ, FRTC, and FRTA scenarios, respectively. Electricity contributes about half of the reduction. Like the results in 
Table 3 Government revenue changes.

\begin{tabular}{|c|c|c|c|c|c|c|c|c|}
\hline $\begin{array}{l}\text { Sources } \\
\text { Unit }\end{array}$ & \multicolumn{2}{|l|}{ Direct tax } & \multicolumn{2}{|c|}{ Indirect tax } & \multicolumn{2}{|l|}{ Tariff } & \multicolumn{2}{|l|}{ Total } \\
\hline$\overline{C T D}$ & 102.37 & 3.89 & 1584.45 & 20.31 & 1.27 & 0.49 & 1688.10 & 15.79 \\
\hline RTC & 0.09 & 0.00 & 366.83 & 4.70 & 1.40 & 0.54 & 368.32 & 3.44 \\
\hline RTA & 0.09 & 0.00 & 366.83 & 4.70 & 1.40 & 0.54 & 368.32 & 3.44 \\
\hline FCTD & 117.49 & 4.47 & 1772.82 & 22.73 & 0.96 & 0.37 & 1891.27 & 17.69 \\
\hline FRTA & 1.30 & 0.05 & 392.16 & 5.03 & 1.15 & 0.44 & 394.62 & 3.69 \\
\hline
\end{tabular}

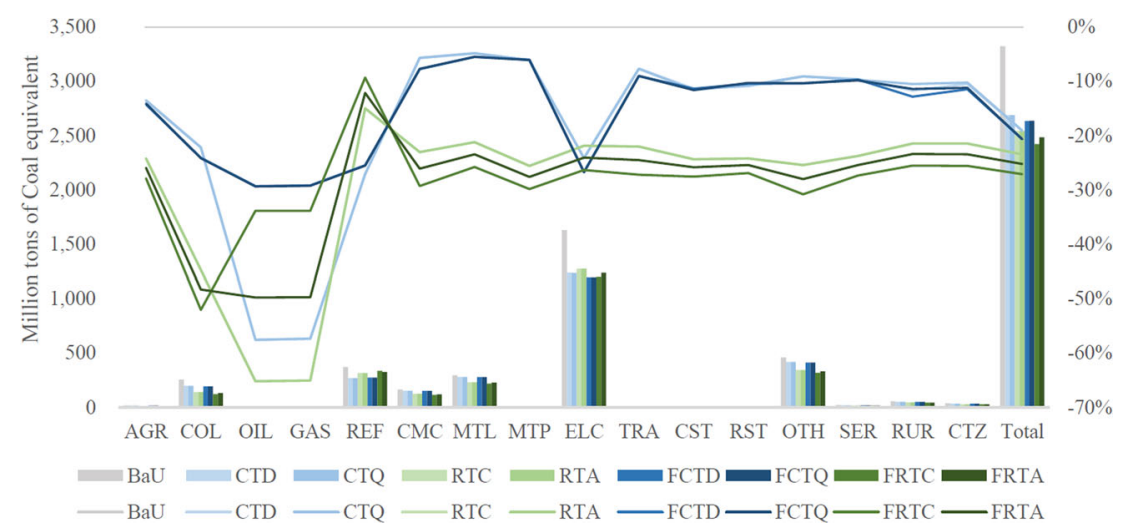

Fig. 10 Coal consumption in 2030. Blue bars/lines are scenarios imposing carbon taxes, and green bars/lines are scenarios imposing resource taxes. Deeper colors represent free market condition in these scenarios. Please refer to Table 2 for industry abbreviations.

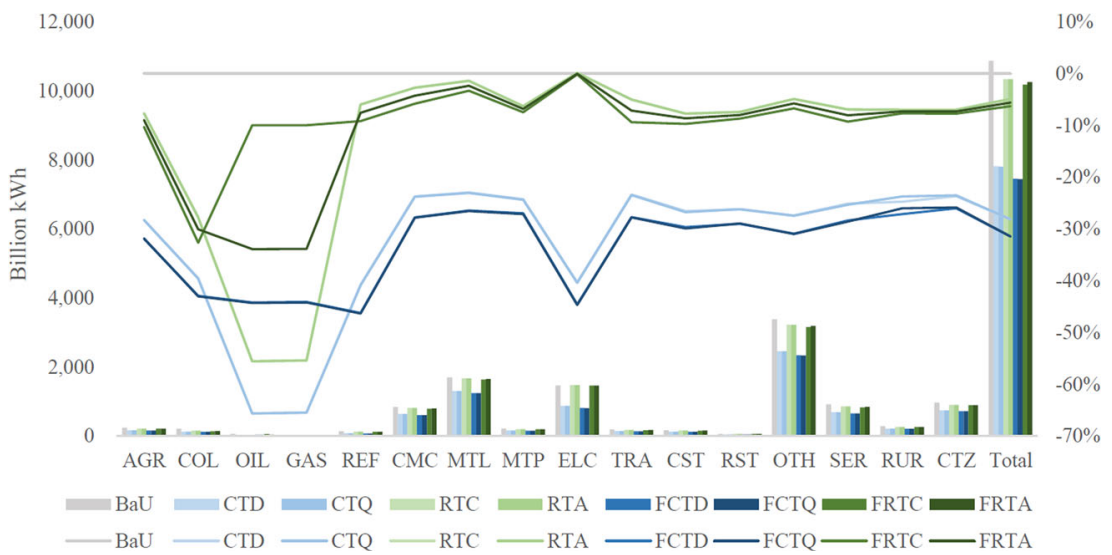

Fig. 11 Electricity consumption in 2030. Blue bars/lines are scenarios imposing carbon taxes, and green bars/lines are scenarios imposing resource taxes. Deeper colors represent free market condition in these scenarios. Please refer to Table 2 for industry abbreviations.

section "Domestic market". RT will result in lower coal consumption than CT, especially in free market condition. Both of the taxes can reduce coal consumption in electricity in similar rates.

The consumption of electricity in 2030 different scenarios are depicted in Fig. 11. The bar and the coordinates on the left represent electricity consumption. The line and the coordinates on the right represent change rates in electricity consumption in 2030. Electricity consumption will be 10868.89 billion $\mathrm{kWh}$ in 2030 . While the consumption will be $7811.39,7807.51,10335.80$, 10335.80, 7451.28, 7448.19, 10181.75, and 10260.78 billion $\mathrm{kWh}$ in CTD, CTQ, RTC, RTA, FCTD, FCTQ, FRTC, and FRTA scenarios, respectively. The changes in electricity consumption is completely different from the changes in coal consumption. Both
$\mathrm{CT}$ and RT reduce coal consumption, however, the reduction in electricity consumption in CT scenarios is significantly greater than that in RT scenarios. This also proves that RT is more friendly to economic development in the other side. Due to the differences in electricity price (Fig. 6), electricity consumption will be totally different in all industries.

\section{Sensitivity analysis}

As the model results may be sensitive to the elasticities of CES functions, we conduct a sensitivity analysis to test whether the results are reliable, as shown in Table 4 . The table shows the percentage of GDP and social welfare changes in all scenarios compared with $\mathrm{BaU}$ scenario under different conditions. We find that all elasticity of production function rise or drop by $1 \%$, the 
Table 4 Sensitivity analysis.

\begin{tabular}{|c|c|c|c|c|c|c|c|c|c|}
\hline & $\mathrm{BaU}$ & CTD & CTQ & RTC & RTA & FCTD & FCTQ & FRTC & FRTA \\
\hline GDP & $0.00 \%$ & $-2.01 \%$ & $-2.02 \%$ & $-1.07 \%$ & $-1.07 \%$ & $-1.89 \%$ & $-1.91 \%$ & $-0.73 \%$ & $-0.86 \%$ \\
\hline Rural welfare & $0.00 \%$ & $-5.71 \%$ & $-4.53 \%$ & $-1.50 \%$ & $-1.50 \%$ & $-6.09 \%$ & $-4.75 \%$ & $-1.24 \%$ & $-1.36 \%$ \\
\hline \multicolumn{10}{|c|}{ Elasticity of production function unchanged } \\
\hline GDP & $0.00 \%$ & $-1.97 \%$ & $-1.98 \%$ & $-1.05 \%$ & $-1.05 \%$ & $-1.85 \%$ & $-1.86 \%$ & $-0.71 \%$ & $-0.85 \%$ \\
\hline Rural welfare & $0.00 \%$ & $-5.65 \%$ & $-4.47 \%$ & $-1.48 \%$ & $-1.48 \%$ & $-6.03 \%$ & $-4.70 \%$ & $-1.22 \%$ & $-1.35 \%$ \\
\hline GDP & $0.00 \%$ & $-1.93 \%$ & $-1.94 \%$ & $-1.04 \%$ & $-1.04 \%$ & $-1.73 \%$ & $-1.76 \%$ & $-0.70 \%$ & $-0.83 \%$ \\
\hline Rural welfare & $0.00 \%$ & $-5.58 \%$ & $-4.42 \%$ & $-1.47 \%$ & $-1.47 \%$ & $-5.74 \%$ & $-4.49 \%$ & $-1.21 \%$ & $-1.34 \%$ \\
\hline Urban welfare & $0.00 \%$ & $-4.71 \%$ & $-4.48 \%$ & $-1.56 \%$ & $-1.56 \%$ & $-4.78 \%$ & $-4.56 \%$ & $-1.30 \%$ & $-1.42 \%$ \\
\hline
\end{tabular}

results doesn't change much. Higher elasticity will ease the loss of GDP and welfare, but can hardly change the difference between $\mathrm{RT}$ and CT, which are the main conclusion of this paper.

\section{Conclusions, policy implication, and limitations}

Conclusions. This paper constructs a dynamic recursive CGE model to analyze the different effects of resource tax and carbon tax, considering different tax form, price-controlled or not, and the same emission reduction goals. This paper finds some interesting findings, such as the completely different mechanism of the demand control and the supply control, which are listed below:

1. Resource tax has a better economic performance than carbon tax (section "GDP"). The GDP loss will be cut in half when applying resource tax to reduce carbon emissions instead of using carbon tax. And the economic gains will increase in the condition of oil and gas market without the price control.

2. In the case of the price control, it would be meaningless to impose a resource tax on oil and gas (section "GDP”). The government is both a tax collector and a subsidizer in the two market.

3. After market prices are no longer regulated, energy consumers will prefer use more oil and gas instead of coal (section "Domestic market"). More importantly, free market of oil and gas results in a better economic performance.

4. Both of resource tax and carbon tax can reduce export of energy commodities. But there is a difference in the behavior of import: resource tax can promote the import of energy, while carbon tax cannot (section "International market"). It is because that carbon tax reduces the demand of energy consumption, while energy resource tax only increases the domestic energy price. Energy consumers are more willing to use imported energy in resource tax scenarios.

5. Under the same reduction goal, carbon tax could significantly increase the tax revenue of the government, while resource tax has relatively low promotion for government revenue (section "Tax rate and government tax"). Moreover, under the same reduction goal, resource tax rate should be higher than carbon tax rate (section "Tax rate and government tax"). As carbon tax is collected from all industries while resource tax is not.

6. Resource tax could reduce more coal consumption than carbon tax, and free market condition could increase more electricity consumption compared with price-controlled condition (section "Coal and electricity consumption"). As the electricity price is higher in carbon tax scenarios, electricity consumption will reduce.

In this paper, we find that resource tax has lower emission reduction cost than carbon tax (Figs. 2 and 3). The result is against overwhelming literature on this topic. Therefore, we must provide the story lines of our findings about the difference between the supply control and the demand control, and why the supply control seems to be better than the demand one.

The effect of full coverage of CT with a closed market without international trade may be the same as the effect of RT. But in reality, it is not the case. Based on our analysis, the tax will rise domestic energy prices, especially in RT scenarios (results in section "Domestic market"). Then, what we find is the economy will pursue maximizing benefits and tend to increase the energy import or the proportion of it (results in section "International market").

Different behaviors emerge when it comes to international trade (results in section "International market"). Once tax imposed on demander (CT), the energy users will reduce their consumptions, both on domestic energy and imported energy. The energy cost of energy users will increase no matter which market they go to buy. But RT is not. Tax imposed on supplier (RT) will affect the price of domestic energy directly, but do not directly affect the cost of energy users for imported energy so that comprehensive energy cost of energy users is lower in RT scenarios.

Based on the social cost of RT is focused more on energy production industries than that of CT (Figs. 5 and 6). To some extent, RT protects the interests of more enterprises. Combining the analysis above, it is clear that the economic loss of RT is smaller under the same emission reduction effect (Fig. 3).

Policy implication. This paper provides several policy implications based on the findings. First, free the energy market can make resource tax be more useful and take more economic gains. Second, as electricity consumption will suffer a huge loss in carbon tax scenarios, necessary subsidy to electricity enterprises should be taken into account if a country implements a high carbon tax to all enterprises. Third, under the same reduction goal, resource tax rate should be higher than carbon tax rate. Last but most important implication is how resource tax works and why resource tax is better than carbon tax, seeing the following statements.

Based on the above conclusions of this paper. We find that it is totally different in how these two reduction policies work. The key finding is that carbon tax reduces the energy demand of 

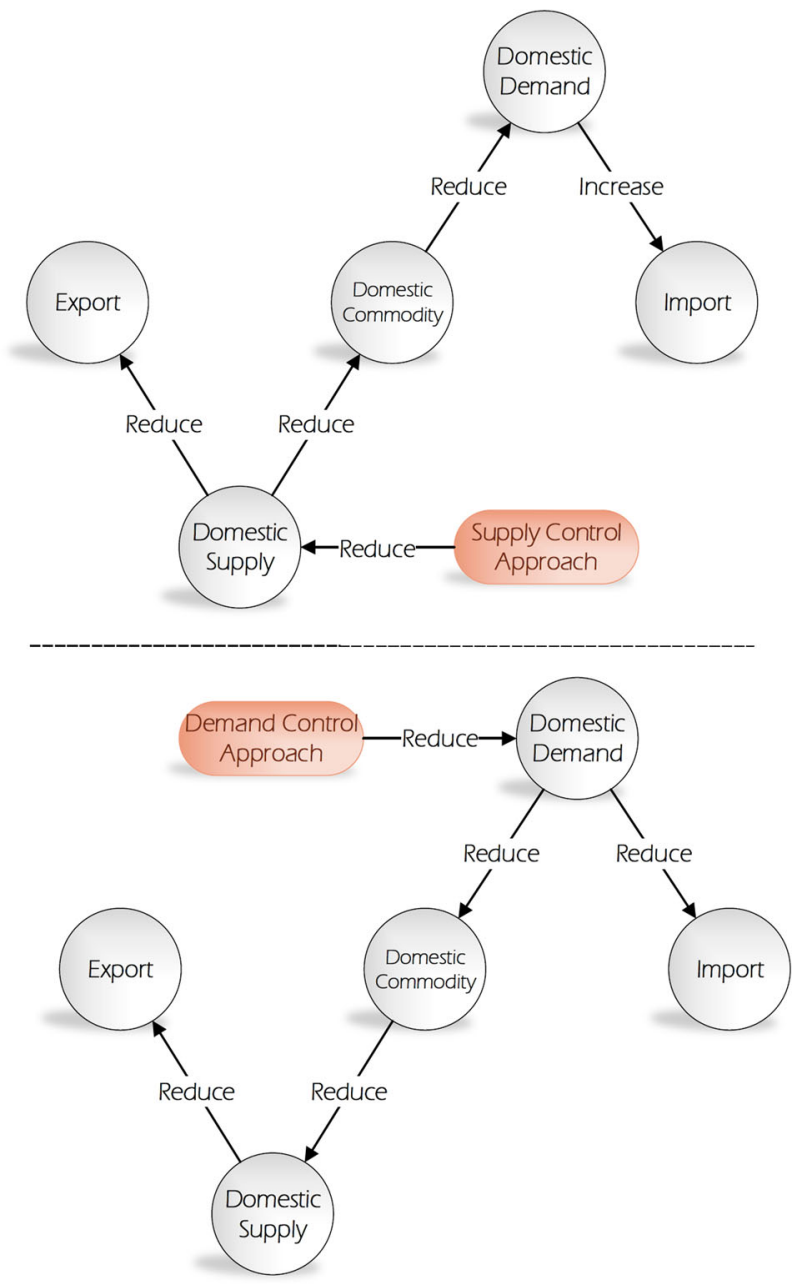

Fig. 12 Key findings of this paper. The arrow represents the chain of influence (increase/positive or decrease/negative).

consumers, which is a demand control approach. While resource tax increases the domestic energy prices and reduces domestic energy output (Fig. 12), which is a supply control approach. The effect may be the same if the market is a closed market in a region. But things go different when it comes to an opening market: It seems that a country in the resource tax scenarios will "enjoy" economic gains from other countries, especially from those energy exporters. A country in resource tax scenarios will use energy resources from other countries to benefit themselves. That's exactly the advantage of resource tax.

Thus, this paper believes that resource tax may be an excellent emission reduction tool for a country to reduce $\mathrm{CO}_{2}$ emissions. The resource tax has lower emission reduction cost than carbon tax. It can reduce emissions while protecting the competitiveness of domestic enterprises (except for energy production industries). Thus, this paper believes that there is an incentive to implement such policy for a country as there is an obvious benefit in the context of global emission mitigation. The amount of the benefits may be related to how many countries do not use resource tax as emission reduction policy in the context of international mandatory emission reductions.

However, we also guess that if all the countries impose resource tax as emission mitigation policy, the cost-benefit of resource tax may be similar to the cost of carbon tax. It is like a prisoner's dilemma. But, has not the global emission reduction target been achieved? The result is what we want.
Limitations and possible future research. In this paper, the rate of resource tax is measured by carbon content in all kinds of fossil fuels. However, the resource tax rates of different quality and different energy sources are different. In this paper, we have to ignore the different tax rate among different qualities of fossil fuels, as CGE model could not distinguish different qualities of the products. Thus, the main feature of resource tax simulated in this paper is the supply control, and then comparing that with carbon tax. The role of resource tax in protecting resources cannot be directly reflected in this paper.

This paper holds an idea that resources tax would increase the energy import of the country. However, the issue of energy import is a comprehensive issue involving politics, endowment, and economy. Crude oil endowment is limited in many oil import countries, such as China. So, for the economic benefit, these countries tend to import more crude oil. But for political stability and economic security, these countries usually maintain the capacity of domestic crude oil producers even if the production is low. So somehow our conclusion of the energy import should be that resources tax would increase the incentives of increasing energy import in the country. The behavior of the energy import is an issue that is worth further explore.

\section{Data availability}

Most data generated or analyzed during this study are included in this published article. As other data, they are available from the corresponding author on reasonable request. In detail, the original input output table is derived from public domain resources: http://www.stats.gov.cn/ztjc/tjzdgg/trccxh/zlxz/trccb/201701/ t20170113_1453448.html. The physical energy consumption data is from the China statistical yearbook: http://www.stats.gov.cn/ tjsj/ndsj/.

Received: 19 December 2019; Accepted: 14 July 2020; Published online: 25 August 2020

\section{Notes}

1 The resource tax this paper mentioned is energy resource tax. Other resource taxes are not the scope of this paper.

2 This paper only considers the carbon dioxide emissions caused by energy consumption, and does not consider other carbon dioxide emissions such as animal and plant respiration, biological decomposition etc.

3 China Carbon Emission Trading Network. An Analysis of the Current Situation of Carbon Taxation in Denmark. Available online: http://www.tanpaifang.com/tanshui/ 2014/0907/37697.html.

\section{References}

Allan G, Lecca P, McGregor P, Swales K (2014) The economic and environmental impact of a carbon tax for Scotland: a computable general equilibrium analysis. Ecol Econ. https://doi.org/10.1016/j.ecolecon.2014.01.012

Apesteguia J, Ballester MA (2015) A measure of rationality and welfare. J Polit Econ 123:1278-1310. https://doi.org/10.1086/683838

Arndt C, Pauw K, Thurlow J (2012) Biofuels and economic development: a computable general equilibrium analysis for Tanzania. Energy Econ. https:// doi.org/10.1016/j.eneco.2012.07.020

Aune M, Godbolt ÅL, Sørensen KH et al. (2016) Concerned consumption. Global warming changing household domestication of energy. Energy Policy 98:290-297. https://doi.org/10.1016/j.enpol.2016.09.001

aus dem Moore N, Großkurth P, Themann M (2019) Multinational corporations and the EU Emissions Trading System: the specter of asset erosion and creeping deindustrialization. J Environ Econ Manage 94:1-26. https://doi.org/ 10.1016/j.jeem.2018.11.003

Barragán-Beaud C, Pizarro-Alonso A, Xylia M et al. (2018) Carbon tax or emissions trading? An analysis of economic and political feasibility of policy mechanisms for greenhouse gas emissions reduction in the Mexican power sector. Energy Policy 122:287-299. https://doi.org/10.1016/j.enpol.2018.07.010 
Bernard J-T, Kichian M (2019) The long and short run effects of British Columbia's carbon tax on diesel demand. Energy Policy 131:380-389. https://doi.org/ 10.1016/j.enpol.2019.04.021

Berry A (2019) The distributional effects of a carbon tax and its impact on fuel poverty: a microsimulation study in the French context. Energy Policy 124:81-94. https://doi.org/10.1016/j.enpol.2018.09.021

Bjerkholt O, Førsund FR, Holmøy E (2016) Commemorating Leif Johansen (1930-1982) and his pioneering computable general equilibrium model of 1960. J Policy Model 38:415-420. https://doi.org/10.1016/j.jpolmod.2016.02.008

Chen W, Hu Z-H (2018) Using evolutionary game theory to study governments and manufacturers' behavioral strategies under various carbon taxes and subsidies. J Clean Prod 201:123-141. https://doi.org/10.1016/j.jclepro.2018.08.007

Chen W, Zhou JF, Li SY, Li YC (2017) Effects of an energy tax (carbon tax) on energy saving and emission reduction in guangdong province-based on a CGE model. Sustain 9. https://doi.org/10.3390/su9050681

China Input-Output Association (2015) 2010 Input-Output Table. http://www. iochina.org.cn/Download/xgxz.html. Accessed 3 Feb 2018

Feng K, Hubacek K, Liu Y et al. (2018) Managing the distributional effects of energy taxes and subsidy removal in Latin America and the Caribbean. Appl Energy 225:424-436. https://doi.org/10.1016/j.apenergy.2018.04.116

Ge J, Lei Y (2018) Resource tax on rare earths in China: policy evolution and market responses. Resour Policy 59:291-297. https://doi.org/10.1016/j. resourpol.2018.07.016

Hagmann D, Ho EH, Loewenstein G (2019) Nudging out support for a carbon tax. Nat Clim Chang 9:484-489. https://doi.org/10.1038/s41558-019-0474-0

Haites E (2018) Carbon taxes and greenhouse gas emissions trading systems: what have we learned? Clim Policy 18:955-966. https://doi.org/10.1080/ 14693062.2018 .1492897

He S, Yin J, Zhang B, Wang Z (2018) How to upgrade an enterprise's low-carbon technologies under a carbon tax: the trade-off between tax and upgrade fee. Appl Energy 227:564-573. https://doi.org/10.1016/j.apenergy.2017.07.015

Hoffmann AN (2003) Imperfect competition in computable general equilibrium models-a primer. Econ Model 20:119-139. https://doi.org/10.1016/S02649993(01)00088-8

Hosoe N, Gasawa K, Hashimoto H (2010) Textbook of computable general equilibrium modelling: programming and simulations. St Martin's Press Palgrave Macmillan, New York, 2010, pp xix, 235, 2-xix, 235

Insley M (2017) Resource extraction with a carbon tax and regime switching prices: exercising your options. Energy Econ. https://doi.org/10.1016/j.eneco.2017.07.013

Jia J, Ma G (2017) Do R\&D tax incentives work? Firm-level evidence from China. China Econ Rev 46:50-66. https://doi.org/10.1016/j.chieco.2017.08.012

Ju Y, Fujikawa K (2019) Modeling the cost transmission mechanism of the emission trading scheme in China. Appl Energy 236:172-182. https://doi.org/ 10.1016/j.apenergy.2018.11.068

Kajackaite A, Gneezy U (2017) Incentives and cheating. Games Econ Behav 102:433-444. https://doi.org/10.1016/j.geb.2017.01.015

Karapinar B, Dudu H, Geyik O, Yakut AM (2019) How to reach an elusive INDC target: macro-economic implications of carbon taxation and emissions trading in Turkey. Clim Policy 1-16. https://doi.org/10.1080/14693062.2019.1635875

Konan DE, Van Assche A (2007) Regulation, market structure and service trade liberalization. Econ Model. https://doi.org/10.1016/j.econmod.2007.03.005

Kosnik L-R (2018) Cap-and-trade versus carbon taxes: which market mechanism gets the most attention? Clim Change 151:605-618. https://doi.org/10.1007/ s10584-018-2330-z

Lawley C, Thivierge V (2018) Refining the evidence: British Columbia's carbon tax and household gasoline consumption. Energy J 39: https://doi.org/10.5547/ 01956574.39.2.claw

Le Quéré C, Andrew RM, Friedlingstein P et al (2017) Global Carbon Budget 2017. Earth Syst Sci Data Discuss 1-79. https://doi.org/10.5194/essd-2017-123

Leslie G (2018) Tax induced emissions? Estimating short-run emission impacts from carbon taxation under different market structures. J Public Econ 167:220-239. https://doi.org/10.1016/j.jpubeco.2018.09.010

Li H, Xiong Z, Xie Y (2018a) Resource tax reform and economic structure transition of resource-based economies. Resour Conserv Recycl 136:389-398. https://doi.org/10.1016/j.resconrec.2018.05.014

Li W, Jia Z (2017) Carbon tax, emission trading, or the mixed policy: which is the most effective strategy for climate change mitigation in China? Mitig Adapt Strateg Glob Chang 22:973-992. https://doi.org/10.1007/s11027-016-9710-3

Li Z, Dai H, Sun L et al. (2018b) Exploring the impacts of regional unbalanced carbon tax on CO2emissions and industrial competitiveness in Liaoning province of China. Energy Policy 113:9-19. https://doi.org/10.1016/j.enpol.2017.10.048

Liang Q-M, Wang T, Xue M-M (2016) Addressing the competitiveness effects of taxing carbon in China: domestic tax cuts versus border tax adjustments. J Clean Prod 112:1568-1581. https://doi.org/10.1016/j.jclepro.2015.02.092

Lin B, Jia Z (2018) The energy, environmental and economic impacts of carbon tax rate and taxation industry: a CGE based study in China. Energy 159:558-568. https://doi.org/10.1016/j.energy.2018.06.167
Lin B, Jia Z (2019) Energy, economic and environmental impact of government fines in China's carbon trading scheme. Sci Total Environ 667:658-670. https://doi.org/10.1016/j.scitotenv.2019.02.405

Liu H, Chen ZM, Wang J, Fan J (2017) The impact of resource tax reform on China's coal industry. Energy Econ 61:52-61. https://doi.org/10.1016/j. eneco.2016.11.002

Lontzek TS, Cai Y, Judd KL, Lenton TM (2015) Stochastic integrated assessment of climate tipping points indicates the need for strict climate policy. Nat Clim Chang. https://doi.org/10.1038/nclimate2570

Lozano FJ, Lozano R, Freire P et al. (2018) New perspectives for green and sustainable chemistry and engineering: Approaches from sustainable resource and energy use, management, and transformation. J Clean Prod 172:227-232. https://doi.org/10.1016/j.jclepro.2017.10.145

Mardones C, Flores B (2018) Effectiveness of a $\mathrm{CO} 2$ tax on industrial emissions. Energy Econ 71:370-382. https://doi.org/10.1016/j.eneco.2018.03.018

Marron DB, Toder EJ (2014) Tax policy issues in designing a carbon tax. American Economic Review

Massiani J (2018) Assessing the economic impact of mega events using computable general equilibrium models: promises and compromises. Econ Model 75:1-9. https://doi.org/10.1016/j.econmod.2018.05.021

McLaughlin C, Elamer AA, Glen T et al. (2019) Accounting society's acceptability of carbon taxes: expectations and reality. Energy Policy 131:302-311. https:// doi.org/10.1016/j.enpol.2019.05.008

National Bureau of Statistics (2015) China Statistical Yearbook (2014). http://www. stats.gov.cn/tijj/ndsj/. Accessed 3 Feb 2018

Nong D (2018) General equilibrium economy-wide impacts of the increased energy taxes in Vietnam. Energy Policy 123:471-481. https://doi.org/10.1016/j. enpol.2018.09.023

Orlov A (2015) An assessment of proposed energy resource tax reform in Russia: a static general equilibrium analysis. Energy Econ 50:251-263. https://doi.org/ 10.1016/j.eneco.2015.05.011

Pizer WA, Sexton S (2019) The distributional impacts of energy taxes. Rev Environ Econ Policy 13:104-123. https://doi.org/10.1093/reep/rey021

Pradhan BB, Shrestha RM, Limmeechokchai B (2020) Achieving the Paris Agreement's 2 degree target in Nepal: the potential role of a carbon tax. Clim Policy 20:387-404. https://doi.org/10.1080/14693062.2020.1740149

Raux C, Croissant Y, Pons D (2015) Would personal carbon trading reduce travel emissions more effectively than a carbon tax? Transp Res Part D Transp Environ 35:72-83. https://doi.org/10.1016/j.trd.2014.11.008

Saboori B, Sulaiman J (2013) Environmental degradation, economic growth and energy consumption: Evidence of the environmental Kuznets curve in Malaysia. Energy Policy 60:892-905. https://doi.org/10.1016/j.enpol.2013.05.099

Speck S (1999) Energy and carbon taxes and their distributional implications. Energy Policy 27:659-667. https://doi.org/10.1016/S0301-4215(99)00059-2

Tang L, Shi J, Yu L, Bao Q (2017) Resources, Conservation and Recycling Economic and environmental influences of coal resource tax in China: A dynamic computable general equilibrium approach. "Resources, Conserv Recycl 117:34-44. https://doi.org/10.1016/j.resconrec.2015.08.016

Voorspools K, Peersman I, D'haeseleer W (2005) A comparative analysis of energy and $\mathrm{CO} 2$ taxes on the primary energy mix for electricity generation. Int $\mathrm{J}$ Energy Res 29:879-890. https://doi.org/10.1002/er.1101

Wang J, Gu F, Liu Y et al. (2019) Bidirectional interactions between trading behaviors and carbon prices in European Union emission trading scheme. J Clean Prod 224:435-443. https://doi.org/10.1016/j.jclepro.2019.03.264

Wang X, Li JF, Zhang YX (2011) An analysis on the short-term sectoral competitiveness impact of carbon tax in China. Energy Policy 39:4144-4152. https:// doi.org/10.1016/j.enpol.2011.04.020

Weitzman ML (1974) Prices vs. quantities. Rev Econ Stud 41:477. https://doi.org/ $10.2307 / 2296698$

Wier M, Birr-Pedersen K, Jacobsen HK, Klok J (2005) Are CO2 taxes regressive? Evidence from the Danish experience. Ecol Econ. https://doi.org/10.1016/j. ecolecon.2004.08.005

Xu J-H, Fan Y, Yu S-M (2014) Energy conservation and CO 2 emission reduction in China's 11th Five-Year Plan: a performance evaluation. Energy Econ 46:348-359. https://doi.org/10.1016/j.eneco.2014.10.013

$\mathrm{Xu} \mathrm{X}, \mathrm{Xu} \mathrm{X}$, Chen Q, Che Y (2018) The impacts on CO2 emission reduction and haze by coal resource tax reform based on dynamic CGE model. Resour Policy 58:268-276. https://doi.org/10.1016/j.resourpol.2018.05.015

Yan S, Eskeland GS (2018) Greening the vehicle fleet: Norway's CO2-differentiated registration tax. J Environ Econ Manage 91:247-262. https://doi.org/10.1016/ j.jeem.2018.08.018

Zhang Z, Guo J, Qian D et al. (2013) Effects and mechanism of influence of China's resource tax reform: a regional perspective. Energy Econ 36:676-685. https:// doi.org/10.1016/j.eneco.2012.11.014

Zhong M, Liu Q, Zeng A, Huang J (2018) An effects analysis of China's metal mineral resource tax reform: a heterogeneous dynamic multi-regional CGE appraisal. Resour Policy 58:303-313. https://doi.org/10.1016/j.resourpol.2018.05.020 
Zhou DQ, Wang Q, Su B et al. (2016) Industrial energy conservation and emission reduction performance in China: a city-level nonparametric analysis. Appl Energy 166:201-209. https://doi.org/10.1016/j.apenergy.2015.09.081

Zhou K, Yang S, Shen C et al. (2015) Energy conservation and emission reduction of China's electric power industry. Renew Sustain Energy Rev 45:10-19. https://doi.org/10.1016/j.rser.2015.01.056

Zou L, Xue J, Fox A, Meng B (2018) The emissions reduction effect and economic impact of an energy tax vs. A carbon tax in china: a dynamic cge model analysis. Singapore Econ Rev. https://doi.org/10.1142/S021759081740015X

\section{Acknowledgements}

The paper is supported by Report Series from Ministry of Education of China (No.10JBG013). We also thank to the help of professor Kerui Du in Xiamen university when we first came up with this idea.

\section{Competing interests}

The authors declare no competing interests.

\section{Additional information}

Supplementary information is available for this paper at https://doi.org/10.1057/s41599020-00569-w.
Correspondence and requests for materials should be addressed to Z.J.

Reprints and permission information is available at http://www.nature.com/reprints

Publisher's note Springer Nature remains neutral with regard to jurisdictional claims in published maps and institutional affiliations.

cc (i) Open Access This article is licensed under a Creative Commons Attribution 4.0 International License, which permits use, sharing, adaptation, distribution and reproduction in any medium or format, as long as you give appropriate credit to the original author(s) and the source, provide a link to the Creative Commons license, and indicate if changes were made. The images or other third party material in this article are included in the article's Creative Commons license, unless indicated otherwise in a credit line to the material. If material is not included in the article's Creative Commons license and your intended use is not permitted by statutory regulation or exceeds the permitted use, you will need to obtain permission directly from the copyright holder. To view a copy of this license, visit http://creativecommons.org/ licenses/by/4.0/

(C) The Author(s) 2020 